\title{
A FARMERS' WIVES' SOCIETY IN PIONEER DAYS
}

\author{
By Marx D. Taylor
}

Teacher of English, Grinnell High School

The club women of Iowa may be interested in gaining a glimpse into the prairie homes of the past through the story of the first woman's club in Harrison County, Iowa, retold largely from the records of the three secretaries, Mrs. L. Kellogg, Mrs. B. F. Roberts, and Mrs. W. T. Preston, whose minutes are the most complete and entertaining throughout a period of twentyfive years.

This Farmers' Wives' Society, as it was called, was organized August 7, 1872, at the home of Mrs. William Roberts, by a group of New England women, wives of the first settlers in Harrison County, Iowa, who were denied the privileges enjoyed by town ladies, yet possessed all their social qualities, talents, and culture. Scattered as they were far and wide over the prairie, without near neighbors nor time to visit the nearest of them, unprepared for the many duties devolving upon the pioneer's wife in this western land, many were beginning to feel discouraged and to long for their old homes and the dear, familiar faces. It was natural, therefore, that they should welcome eagerly the suggestion of a woman's society as a means of creating a friendly social feeling among the families in the country, an opportunity for discussing informally those things pertaining to the duties of a farmer's wife, and a relief from the routine and monotony of such a life.

At a subsequent meeting the ladies adopted the following constitution whose articles were frequently to be copied and sent to members who moved away and wished to form similar organizations in their new homes:

Article 1. This society shall be called The Farmers' Wives' Society, and shall meet once in two weeks, at any place designated by the president, for the purpose of promoting social intercourse, and 
profiting by the experience of others, seeking instruction in all the duties relating to the farmer's wife.

Article 2. The officers of said society shall consist of a president, a vice-president, a treasurer, and a secretary. Any lady may become a member by signing the constitution; all money being raised by subscription.

Article 3. That this society may not become a burden and a care to any one person, every lady shall bring from her store of eatables whaterer she may think most convenient; the lady of the house where said society meets providing the tea, butter, biscuits and condiments.

Article 4. That this society may not say bad things while it aims to do good, a fine shall be imposed upon any lady who speaks disparagingly of another.

Article 5. At every meeting some subject shall be presented for consideration at the next meeting, and it may relate to anything that pertains to the happiness or comfort of the farmer's wife.

Article 6. Lest we forget the object of our society and make it an advertisement of the latest styles in fashionable attire, every lady is required to wear a plain home dress.

Article 7. Every lady shall bring her own work, unless some case of destitution or other domestic affliction needs assistance.

Article 8. While this society is designed for the farmer's wife, none are excluded and all are assured of a cordial welcome.

$$
\begin{aligned}
& \text { Mrs. William Roberts, President } \\
& \text { Mrs. Lorenzo Kellogg, Vice-President } \\
& \text { Mrs. Julia W. Olmstead, Treasurer } \\
& \text { Mrs. Laura A. Nay, Secretary }
\end{aligned}
$$

Year by year the organization grew in strength, interest and numbers in spite of one gentleman's remark that no society of women could long exist whose by-laws excluded gossip.

During the early days of its existence, we follow it from house to house up and down Mill Creek, meeting often at the same places as homes and people were few. Gradually it extended its influence and boundaries beyond the Boyer River on the west, the Picayune on the south, and all the way between. As new names continued to be added, the society voted to meet with the members in alphabetical order. It also adopted the plan of meeting in the forenoons during the winter and having dinner instead of suppers so that the farmers could get home before dark.

Throughout its entire history, rotation in office seems to have been the practice. All the officers were expected to do their best 
one year at a time and then gracefully congratulate their successors.

When a few gentlemen first began to attend, the ladies conjectured that these were spies sent out to reconnoiter and proceeded to feast and cajole them, hoping to gain their good will. Evidently the plan succeeded, as it is recorded that at one gathering there were twenty-five gentlemen present and "they talked and laughed for all the world like a lot of women."

The programs consisted mainly of lively discussions of the making of bread, butter, cheese, cake, and pickles; of the canning of fruit and the making of pies-timeworn themes that never really grow old. Candle dipping and quilt piecing received their share of attention. Had it not been for their society the ladies might never have known that "housekeeping could not be reduced to a perfect science," nor that "walking out of doors in January with nothing on the feet but slippers was a dangerous practice and sure to result in ill health." House cleaning was another topic they discussed with more or less wisdom. One room at a time was considered the best way. Ammonia figured largely in the program as an antidote for dirt. The subject seemed to admit of various digressions, such as bedbugs, red ants, moths and cats. Naphtha was decided to be the grand exterminator of all these household pests except the cats. These, people could keep or not, just as they pleased. No sympathy was expressed for the owners of a surplus number of cats.

Helpful articles were read from The Household, a magazine for which the society subscribed many years. Sometimes each member had a subject of her own, such as knitting, pickles, temperance, school, Sabbath observance, camp meeting, threshing machine, picnic, polonaise pattern, or cyclone. The one drawback was that they all tried to talk at once and so lacked listeners. On one such occasion a cry came from the room in which the young ladies were sitting that the old people were making more than their share of noise. It seems that the nerves of the former had been shocked in their efforts to kill a mouse which had been caught in a trap, though some six had assisted in the undertaking and the cat had come in on the home stretch. 
At other times somebody would tell an anecdote which would make somebody else think of another, and thus they would laugh and talk till tea time. No secretary ever failed to state that all were in the best of moods, or that the meeting broke up with the company in a jolly good humor. The records of the society are replete with incident, but three features are always present in the minutes. These are the spirit of friendliness and good will, the bountifully supplied table, and the state of the weather.

One secretary at the close of her term of office remarks that the year had been a pleasant one and she trusts the remembrance of their kindly greetings and words of cheer had lightened the burdens of some and increased the joys of others. Another writes that she is glad to see this one present and hopes she'll come again; is sorry that a certain one is ill; is glad another is better; regrets that some one is moving away; expresses sympathy for one who has lost her home by fire; is saddened by the death of a loved one; wishes a new bride much happiness; or hopes that the day for the next meeting will be pleasant as the hostess enjoys a houseful. A third tells us that there had been floods, famine, and pestilence in many places; sickness and death were everywhere; but no member of the society had died that year and they had great cause for thankfulness.

Second only to the spirit of fellowship and good cheer were the bountiful dinners. We frequently read that "the table fairly groaned under its load of good things, but all took hold and assisted in lightening the burden and accomplished wonders. Quite a number of gentlemen assisted in the work." Or again when the latter had completely. surrounded the table, "the ladies looked on complacently as they had had their fill. But the loaded tables nonplused even the gentlemen, and the juveniles who supped at the third table had a plenty." On one never to be forgotten occasion every one happened to bring a pie as her contribution. Usually, however, there was a choice variety. One lady who felt obliged to sample each kind of sponge cake and seed cookies is reported to have had a severe time, but came safely through it. 
The weather seemed to be an unfailing topic of interest. We read of the Slough of Despond through which certain members had to pass, of the dust the hostess' little broom brushed off, of the snow banks through which they floundered, of the cold blustering days, and of the mercury raging frantically around one hundred degrees in the shade. But in spite of storm and sunshine, wind and mud, farmers' wives were brave, and they continued to come from the north and the south, the east and the west.

One blizzardy day the society which was to meet with Mrs. Jennings proved to be a surprise party. The hostess' husband had informed her that not a person would think of venturing out on such a day, so she made no special preparations. Before noon, however, the house was well filled and willing hands worked lively in assisting the hostess prepare food and tables. Mr. Jennings had not been acquainted with the Farmers' Wives' Society long enough to learn that neither fire nor flood, cold nor heat, would prevent its assembling at the appointed time. Once, however, on a bitter cold day when the members were attempting to drive over the hills during a blinding snow storm, they were stopped by a snow drift and had to return home. The poor hostess waited in suspense, looking from one window, then another, until the wintry afternoon wore away. Her family had to eat biscuits steamed, biscuits toasted, and biscuits dried for at least a fortnight.

No matter how sultry the weather, the annual picnic in August was always a grand and joyous occasion. Each farmer's wife was expected to bring her whole family, cook all the nice things she could, and provide an abundance of tea coffee, and lemonade. The house would be full and the yard full. Every one would seem happy, especially the gentlemen.

True to their purpose, the meetings of the Farmers' Wives' Society were profitable as well as pleasant. We find the members lending a hand to the settlers of northwest Iowa who were suffering from grasshopper raids. Frequently they mention contributing quilts and garments to the Christian Home in Council Bluffs, and sewing for some of the members who had been ill a long time. 
Once they donated the material and made two dozen garments fo: a family who had lost everything in a tornado.

Scattered through the records are various incidents that happened from time to time, enlivening the gatherings and causing many a hearty laugh. At one meeting a gentleman made a speech on the subject, "Women Lecturers." This was considered remarkably good until he closed with the remark that a certain one whom he had heard lately was the best ever. "Why," he exclaimed, "she spoke like a man!" This rather upset the ladies and caused a lively game of "Spat 'em Out" to be played right there.

One winter day was partially given up to amusements. A pig album contributed largely to the fun. The secretary tells us, "This artistic work was done blindfolded, each one making a drawing of a pig and writing her autograph underneath. And such pigs! Some with ears on their sides, and some with eyes where their nose ought to be, and some with no eyes at all! Most of them had an enormous gap somewhere."

Again, when the crazy quilt fever struck the society, we learn that "a lady, who for forty years had opposed and preached against such foolish work, was on hand with a quilt pattern called the 'elephant's foot,' which contained nobody knows how many hundred little bits-all going to show the utter folly of vowing that one would never, no never, be so silly as to buy whole cloth and cut it into little pieces for the fun of sewing them together again."

Mrs. Kellogg relates that one time when she was ill, she wrote to Mrs. Preston asking her to officiate as secretary in her place. Later Mrs. Preston informed her that the note sent her dated "In Bed" was received by her "In Bed," and she only knew that it was a time of considerable sickness and only about thirty were present; but they probably had a good time and certainly ought to have been thankful that they were not on the sick list.

Mrs. L. E. Jordan, another secretary, recounts that on one occasion she had to spend a part of the time in the kitchen and pantry, but now and then she could catch some of the lively sayings of those in the parlor. As Mrs. Roberts and Mrs. Pres- 
ton were there, she supposed of course the ladies were talking politics, as all wise women should. Suddenly she heard Mrs. Preston say, "Yes! And my sleeves had two full widths of silk." Fancy talking of wedding gowns when they ought to be discussing more important and later date affairs. Well, the secretary once had a wedding gown, and so, being interested, she slyly listened. But only for a moment, for of course (as was her custom) she had to put in her say. Stepping to the door, she called, "Humph! Mine had nine widths in the skirt!" Whereupon Mrs. Preston arose, and, quickly assuming as great a height as was possible for so small a woman, looked very scornfully at the secretary as she replied in scathing tones, "How dared you, when mine had only eight?" Then as her quick wit came to her aid, she continued more serenely, "Oh, I know! My silk was an inch wider than yours; yes, it must have been; or two-yes, I think it was two, and that made my dress a little the wider." And with a happy, convincing smile she resumed her seat and forgot that she had been arguing about wedding finery with Mrs. Roberts, and so peace was restored.

Even the children came in for their share of attention. Much sympathy was expressed for little Hattie who had lost five kittens and had seventeen left. At another time a little boy who brought a wee little lamb into the parlor caused much merriment and conjecture as to whether this was Mary's little lamb. Once when a lady who had been busily knitting something explained that it was a pair of reins for a friend's little boy to play horse with, the mothers agreed that all small boys had a penchant for harnessing all the chairs in the house, and when the chairs gave out, the door knobs. As Mrs. Kellogg was frequently observed to be knitting little mittens too small for her hand, it was evident that some little grandchild was to have warm fingers.

We are told that once during the period when the average attendance was fifty, "only forty-nine were present, but one lady went the next afternoon and that made fifty." The secretary suggested that Mrs. Hillis must be working under next year's 
calendar and proposed that the society furnish her one for the current year.

At times we read of hints of disbanding, but these evidently met with little encouragement, for the farmers' wives had found that the hours of rest and social recreation once in two weeks came none too often. Twenty years rolled by, and at the anniversary meeting, letters were read from former members; all speaking heartily of the good times of yore and expressing good wishes for the future.

On August 10,1898, the twenty-sixth anniversary of the organization, the last regular meeting was held in Dunlap at the hospitable home of Mrs. Lorenzo Kellogg, a charter member of the society. So many of the former members of the society had died or moved away, and the new ones seemed to lack interest, that the members voted to hold the annual picnic at the home of Mrs. B. F. Roberts and then disband. The society had served its purpose in the early day, and, like the old-fashioned Thanksgiving, its anniversary would always bring recollections of pleasure, joyous reunions, and feasts of good things.

On September 6 the farmers and their families gathered from far and near. A bountiful dinner was served under the shadow of the trees, and as usual much merriment and good feeling prevailed. With lively anecdotes and merry conversation the time passed rapidly away. But festive days, like all others, must end. As the sun went down, the Farmers' Wives' Society adjourned, hoping to meet again some anniversary day.

\section{MEMBERS OF THE FARMERS' WIVES' SOCIETY}

Mrs. Maria M. Roberts

Mrs. Julia W. Olmsted

Mrs. Eliza J. Towne

Mrs. Lavina Brown

Mrs. Lydia Hoxsie

Mrs. Lillie M. Tyler

Mrs. Mary B. Kellogg

Mrs. Harriet A. Tyler

Mrs. Laura A: Nay

Mrs. Altha J. Brown

Mrs. Juliett Chapman
Mrs. Celinda Brock

Mrs. F. B. Hoffman

Mrs. M. Roskopf

Mrs. Mary Simpson

Mrs. C. L. Kingsbury

Mrs. Mary Burling

Mrs. A. D. Ewers

Mrs. E. B. Mead

Mrs. Fred Jennings

Miss Lucy Jennings

Mrs. M. L. Jennings 
Mrs. Dora E. Frink Mrs. Lettie E. Jordan Mrs. Hattie R. Hatch Mrs. Nellie C. Roberts Mrs. Almira J. Moore Mrs. Parmelia D. Kellogg Mrs. Emma B. Roberts Mrs. Harriet A. Greene Mrs. Ann Bartlett Mrs. Sarah M. Hyde Mrs. Dorcas French Mrs. Mary Hickox Mrs. Augusta Hammond Mrs. A. N. Warren Mrs. Alley R. Graves Mrs. Cynthia J. Miers Mrs. C. A. Chapman Mrs. H. M. Lowrey Mrs. R. E. Eccleston Mrs. L. E. Brace Mrs. Bartlett Mrs. Matilda Lyman Mrs. Ann E. Lyman Mrs. Orin Hatch Mrs. Angelica Davis Mrs. Margaret Donovan Mrs. Arthur Roberts Mrs. Jane Gilchrist Mrs. Emma Iyman Miss Nellie E. Kellogg Miss Katie Brown Miss Bella Davie Miss Orre E. Green Mrs. Sarah E. Rix Mrs. L. Kentner Mrs. Annie Oakley Mrs. J. E. Emerson Mrs. Mary Jackson Mrs. Susan Gifford Mrs. Charles Sears Mrs. W. T. Preston Mrs. Harlow Mills Mrs. A. B. Pratt Mrs. Nettie Byers
Mrs. S. C. Havecroft Mrs. W. C. Bryan Mrs. Eugene Bryan Mrs. M. E. Riggs Mrs. E. B. Pierce Mrs. S. J. Smith Mrs. L. E. Underhill Mrs. Hettie Bilger Mrs. J. Young Mrs. J. M. Peters Mrs. R. A. Betchel Mrs. Frank Pflieger Mrs. C. A. McGarvey Mrs. S. M. Carpenter Mrs. L. Francis Mrs. R. B. Hillis Mrs. D. R. Rogers Mrs. Fannie Manning Mrs. D. B. Lake Mrs. C. L. True Mrs. S. W. Morton Mrs. A. L. Metaalf Mrs. Jane Havercroft Miss Nellie A. Preston Miss Grace Kellogg Miss Gertie Jordan Mrs. Mae Kellogg Mrs. Will Moore Mrs. Peter Campbell Miss Minnie Roberts Mrs. Nixon Mrs. C. A. Bryan Mrs. Noel Fouts Mrs. James Fouts Mrs. Wm. Fouts Miss Edith Fouts Mrs. Nancy Benjamin Miss Bettle Benjamin Mrs. John Dedrick Mrs. H. M. Hanchett Mrs. J. W. Lawson Mrs. Frank Rogers Mrs. Ella Lyman Mrs. Esther Hall 
Mrs. S. E. Stowell

Mrs. Phebie Weed

Mrs. Hattie Brace

Mrs. M. Smith

Mrs. A. J. Pitts

Mrs. L. M. Wright

Mrs. W. H. Garrett

Mrs. A. I. Maynard

Mrs. Robt. Ramsey

Mrs. James Vanscoy
Mrs. Sarah McCord

Mrs. D. C. Pherguson

Mrs. George Dawson

Mrs. Chas. Jackson

Mrs. Jefferson Watkins

Mrs. Musgrove

Mrs. Terrill Young

Mrs. M. J. Young

Mrs. Chas. Davis

\section{FRUIT TREES FOR WHEAT}

We will sell fruit trees the coming spring for wheat, bacon, beeswax, dry hides, or cash, wheat to be delivered at Shepherd's mills, Des Moines, at the mills of J. D. Parmlo in Warren County, at the nursery at Pella, or at the mills of William Crumpton, near Winterset. One hundred thousand root grafts, set the present winter, will be sold at $\$ 8.00$ per thousand, and two or three years' time given for payment, at 6 per cent., or we will sell for unimproved lands south or west of this.

Two hundred Concord grapes at $\$ 1.00$ each; Burris fine Earl Scarlet and Hoovey's Seedling strawberries at the usual prices.

We will sell to punctual farmers on time. We have very large trees at Pella, Winterset and Des Moines and trees of four years' growth at Indianola and Boonesboro.

James Smith \& Son.

-Tri-Weekly Iowa State Journal, Des Moines, March 1, 1858. (In the newspaper collection of the Historical Department of Iowa.) 
Copyright of Annals of Iowa is the property of State of Iowa, by \& through the State Historical Society of Iowa and its content may not be copied or emailed to multiple sites or posted to a listserv without the copyright holder's express written permission. However, users may print, download, or email articles for individual use. 